\title{
Brachyhypopomus draco, a new sexually dimorphic species of Neotropical electric fish from southern South America (Gymnotiformes: Hypopomidae)
}

\author{
Julia Giora $^{1}$, Luiz R. Malabarba ${ }^{1}$ and William Crampton ${ }^{2}$
}

Brachyhypopomus draco, new species, is described from central, southern and coastal regions of Rio Grande do Sul state, Brazil, and Uruguay. It is diagnosed from congeners by, among other characters, the shape of the distal portion of the caudal filament in mature males, which during the reproductive period forms a distinct paddle shape structure.

Brachyhypopomus draco, espécie nova, é descrita para as regiões central, sul e costeira do estado do Rio Grande do Sul, Brasil, e Uruguai. Ela é diagnosticada de seus congêneres, entre outros caracteres, pela porção final do filamento caudal de machos maduros, que adquire a forma de um remo durante o período reprodutivo, .

Key words: Electric Organ Discharge, EOD, Rio Uruguay, Laguna dos Patos, Rio Tramandaí.

\section{Introduction}

The family Hypopomidae, proposed by Mago-Leccia (1978), is widespread in South American countries, except Chile, and distributed from the río de la Plata in Argentina ( $\left.35^{\circ} \mathrm{S}\right)$ to northern Panama $\left(8^{\circ} \mathrm{N}\right)$ (Albert, 2001). The genus Brachyhypopomus was described by Mago-Leccia (1994) to comprise six species that previously belonged to Hypopomus and that share the characters: short snout, absence of mesocoracoid bridge, short and crescent-shaped maxillary bone, and posterior nares closer to eyes than to snout tip. Later, Albert (2001) redefined the genus based on four synapomorphies: premaxilla gracile with a curved anterior margin and forming a distinct angle with the maxilla in lateral view, dentary gracile, body cavity with 16-17 precaudal vertebrae, single transitional vertebra. Albert (2001) maintained the same six species cited by Mago-Leccia (1994) in the genus. Additionally he listed seven undescribed species and recognized five clades within Brachyhypopomus that were previously proposed by Sulivan (1997).

The six Brachyhypopomus species recognized as valid by Mago-Leccia (1994) and Albert (2001) are: B. brevirostris (Steindachner, 1868), which occurs in Eastern South America from the Orinoco to la Plata drainages; B. occidentalis (Regan, 1914), which occurs in Panama, and in several trans-Andean drainages of north eastern South America, including the Magdalena, Atrato, Catatumbo and Pacific slope rivers; $B$. beebei (Schultz, 1944), which is widespread through tropical areas east of Andes; B. diazi (Fernández-Yépez, 1972), which is restricted to the Caribbean littoral of Northwest Venezuela, from the río Tocuyo to río Alpargaton and also the northern Llanos in the Orinoco basin; B. pinnicaudatus (Hopkins,

${ }^{1}$ Universidade Federal do Rio Grande do Sul, IB, Departamento de Zoologia, Av. Bento Gonçalves, 9500, bloco IV, prédio 43435, 91501970 Porto Alegre, RS, Brazil. jugiora@hotmail.com; malabarb@ufrgs.br

${ }^{2}$ Department of Biology, University of Central Florida, Orlando, 32816-2368, USA. crampton@mail.ucf.edu 
1991), which is widespread through cis-Andean South America, including the Guianas, the Orinoco and Amazon basins, and much of the rio Paraná-Paraguay-Uruguay drainage as far south as the río de la Plata; and B. janeiroensis (Costa \& Campos-da-Paz, 1992), which is known only from the São João and Paraíba do Sul river basins in Rio de Janeiro state (Albert \& Crampton, 2003).

Subsequently, Triques \& Khamis (2003) described $B$. jureiae, which is known to occur in the Una do Prelado river system in southern Brazil, and also from Ribeira de Iguape drainage, near Iguape, São Paulo (Triques \& Khamis, 2003; F. Lima \& W. Crampton, pers. obs.). Loureiro \& Silva (2006) described $B$. bombilla, which is distributed throughout the middle rio Uruguay tributaries and the laguna dos Patos and lagoa Mirim systems in eastern Uruguay.

In Rio Grande do Sul state, southern Brazil, there have been no previous studies of the species diversity of Brachyhypopomus, excepting the occasional mention of the genus in checklists and reviews. The oldest citation was by Ellis (1913), based on specimens identified as Hypopomus brevirostris (=Brachyhypopomus brevirostris) collected by Herman von Ihering in the laguna dos Patos drainage (Malabarba, 1989). Brachyhypopomus pinnicaudatus, B. beebei and an undescribed species have been quoted as widely distributed in cis-Andean South American basins by Sullivan (1997), including material from Rio Grande do Sul state. Brachyhypopomus brevirostris and B. pinnicaudatus have been cited to occur in the la Plata drainage (Campos-da-Paz, 1997; Albert \& Crampton, 2003), and B. beebei from laguna dos Patos drainage (Campos-da-Paz, 1997).

Based upon extensive sampling in Rio Grande do Sul, our studies revealed the presence of three Brachyhypopomus species in this region: $B$. bombilla; a second species that has been largely identified as B. pinnicaudatus in the literature; and a third and new species that is widespread in the rio Uruguay, laguna dos Patos and rio Tramandaí drainages in southern Brazil and Uruguay. This latter species is described herein.

\section{Materials and Methods}

Comparative data from B. pinnicaudatus, B. bombilla and $B$. jureiae were taken directly from the type specimens (see Comparative Material). Data from B. brevirostris, B. occidentalis, B. beebei, B. diazi and B. janeiroensis were compiled from original descriptions. Morphometric data were taken as point-to-point linear distances using digital calipers to the nearest $0.1 \mathrm{~mm}$. Measurements were analyzed as percentage of length to the end of the anal fin (LEA), measured as the distance from tip of the snout to posterior end of anal fin base, or as percentage of head length (HL), measured from tip of snout to posterior margin of bony operculum. Total length was not used as a numerator in morphometric body relationships because of the high number of specimens with a damaged and/or regenerated caudal filament. Regenerated parts of the body were not measured and their meristic data were not recorded. The other measurements used were: caudal filament length, measured from the end of anal fin base to the tip of caudal filament; snout to anal-fin origin, from tip of snout to origin of anal-fin base; depth of caudal filament, measured at the posterior end of anal-fin base; longest analfin ray, from base to tip of the longest ray; pectoral-fin length, from the dorsal border of the fin base where it contacts the cleithrum to tip of the longest ray; body depth, measured at anal-fin origin; snout length, from tip of snout to anterior margin of orbit; gape width, between lateral margins of mouth gape; orbital diameter, between anterior and posterior margins of the orbit; interorbital distance, shortest distance between margins of orbits; posterior nare to eye, from posterior margin of posterior nare to anterior margin of orbit; branchial aperture, from posterodorsal to anteroventral extent of branchial fold; head width at operculum, largest width measured at bony operculum; head width at eyes, head width measured at center of eyes. Pectoral and anal-fin ray counts were taken directly from ethanol preserved specimens under a stereomicroscope. Vertebrae were counted from radiographed specimens including the four vertebrae of the Weberian Apparatus. Apparently, Albert (2001) did not include the vertebrae of the Weberian Apparatus in the precaudal counts; therefore, four vertebrae were added to Albert's (2001) counts for comparison. Osteological data were taken from cleared-andstained (cs) specimens following Taylor \& Van Dyke (1985). Sex and the stage of sexual maturity were determined by dissection, following Cognato \& Fialho (2006).

Fish specimens belong to the collections of Academy of Natural Sciences of Philadelphia, Philadelphia (ANSP), California Academy of Sciences, San Francisco (CAS), Universidade Federal de Minas Gerais, Belo Horizonte (DZUFMG), Museu de Ciências e Tecnologia, Pontifícia Universidade Católica do Rio Grande do Sul, Porto Alegre (MCP), Museu Nacional, Rio de Janeiro (MNRJ), Museu de Zoologia, Universidade de São Paulo, São Paulo (MZUSP), Departamento de Zoologia, Universidade Federal do Rio Grande do Sul, Porto Alegre (UFRGS), University of Michigan Museum of Zoology, Ann Arbor (UMMZ), National Museum of Natural History, Washington D.C. (USNM), Faculdad de Ciências Naturales, Montevideo (ZVC-P).

Electric Organ Discharge (EOD) recordings were taken from fishes obtained from rio Uruguay, rio Tramandaí and laguna dos Patos drainages. Specimens were held in water from the capture locality at $27^{\circ} \mathrm{C}+/-0.5^{\circ} \mathrm{C}$ for at least 12 hours before the recording. All recordings were made in an aquarium maintained at $27^{\circ} \mathrm{C}+/-0.1^{\circ} \mathrm{C}$, containing water from the capture locality (or nearby). Each specimen was allowed 10 minutes to acclimate before recording. Signals were picked up from silver/silver-chloride electrodes placed posterior and 
anterior to the fish and with a ground contact in the center. Individual fish were placed within a nylon-mesh sock. The electrodes were connected to a custom-built AC-coupled differential amplifier with a frequency response of $+/-3 \mathrm{~dB}$ from $0.2 \mathrm{~Hz}-110 \mathrm{kHz}$ (Wells \& Crampton, 2006). EODs were digitized using an Edirol UA5 A-D converter at a sampling rate of $96 \mathrm{kHz}$ and resolution of 24 bits. Recordings of resting repetition rate were taken during daylight hours between 1000 and 1400 from fish held in nylon-mesh socks under subdued lighting. Recordings of nocturnal activity were taken from 1-3 hrs after sunset from single specimens held in $10 \mathrm{l}$ buckets containing water from the source locality, and water hyacinths. An electrode was placed in the center of this tank and the fish was allowed unrestricted movement before and during the recording. All signal analyses were conducted using customwritten MATLAB or Java software designed by W. Crampton. EOD durations were calculated with the beginning and end of the EOD taken at a 1\% threshold of the amplitude of the dominant positive phase (P1) following normalization to the P1 amplitude. EODs recorded from specimens with more than $10 \%$ damage to the caudal filament were not included for waveform analyses.

Calculations of EOD repetition rate were taken by measuring all successive inter-pulse intervals over one minute recordings. The EOD rate for each fish was characterized by three parameters. 1. The mean pulse rate in $\mathrm{Hz}$ calculated as the reciprocal of the mean of all IPIs (in seconds). 2. The standard deviation (SD) around the mean pulse rate in $\mathrm{Hz}$. This measure of variance indicates the stability of the EOD repetition rate. 3 . The coefficient of variance (CV) calculated as a percentage (mean/SD*100). Because the $\mathrm{CV}$ is weighted by the mean, it is used for standardized comparisons of the relative stability of the pulse rate over a wide range of rates. The mean and SD of these three measures were then calculated among all recorded adult or post-larval specimens, and are presented here to summarize diurnal and nocturnal EOD activity.

\section{Results}

\section{Brachyhypopomus draco, new species} Figs. 1, 2

Holotype. MCP 41540, 1 (male, 137.3 mm LEA), Brazil, Rio Grande do Sul, Parque Estadual de Itapuã, lagoa Verde (30²2’52.4"S, 5101'25"W), 12 Jan 2004, D. Cognato, L. R. Malabarba, C. E. Machado \& R. Q. Carvalho.

Paratypes. All from Brazil, Rio Grande do Sul. Laguna dos Patos drainage: MCP 41539, 1 (male, 147.1 mm LEA), collected with the holotype. UFRGS 8888, 1 (male, 126.4 mm LEA), same locality of the holotype, 18 Jan 2006, J. Giora, A. P. Dufech \& J. Ferrer. MNRJ 30916, 2 (1 male, 151.8 mm LEA, 1 female, $128.4 \mathrm{~mm}$ LEA), same locality of the holotype, 9 Feb 2004, D. Cognato, M. Azevedo, A. Schaan \& C. Hiroshi. MCP 41538, 2 (1 male, 88.4 mm
LEA, 1 female, $91.7 \mathrm{~mm}$ LEA), same locality of the holotype, 30 Jun 2004, D. Cognato \& A. Schaan. MNRJ 30917, 1 (male, 150.2 mm LEA), MZUSP 94429, 1 (male, 139.1 mm LEA), same locality of the holotype, 9 Sep 2004, D. Cognato, M. Schossler \& A. Schaan. MCP 41537, 1 (female, 108.4 mm LEA), same locality of the holotype, 10 Oct 2003, D. Cognato \& A. Schaan. MNRJ 30918, 1 (male, $138.2 \mathrm{~mm}$ LEA), same locality of the holotype, $11 \mathrm{Nov}$ 2003, D. Cognato, J. Giora, J. Anza \& A. P. Dufech. UFRGS 732, 1 (female, $78.0 \mathrm{~mm}$ LEA), Viamão, arroio Alexandrina (306' $\mathrm{S}$, 5057’W), 7 Sep 1980, L. R. Malabarba. UFRGS 820, 1 (male, 93.7 mm LEA), Guaíba, açude near BR290 highway ( $\left.30^{\circ} 07^{\prime} \mathrm{S}, 5^{\circ} 20^{\prime} \mathrm{W}\right)$, 4 Nov 1979, L. R. Malabarba, C. F. M. Souto \& P. A. Buckup. UFRGS 822, 1 (male, 92.5 mm LEA), Guaíba, açude in BR290 highway, near junction with BR116 highway ( $\left.30^{\circ} 03^{\prime} \mathrm{S}, 51^{\circ} 21^{\prime} \mathrm{W}\right)$, 18 Jan 1980, P. A. Buckup \& C. Souto. UFRGS 6526, 1 (male, 102. 2 mm LEA), UFRGS 6525, 1 (male, 100.6 mm LEA), Eldorado do Sul, artificial canal near BR290 highway $\left(30^{\circ} 2^{\prime} 55^{\prime \prime S}\right.$,

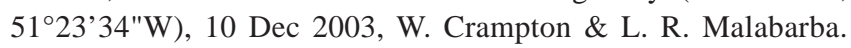
UFRGS 4317, 1 (male, 50.0 mm LEA), Viamão, arroio Itapuã (30¹5’S, 5102'W), 1 Mar 1988, F. Becker \& L. R. Malabarba. Rio Tramandaí drainage: UFRGS 6486, 1 (male, 85.3 mm LEA), UFRGS 6488, 1 (male, 98.1 mm LEA), UFRGS 6489, 1 (male, 100.8 mm LEA), UFRGS 6490, 1 (female, 95.5 mm LEA), UFRGS 6491, 1 (male, 80.9 mm LEA), Capão da Canoa, creek parallel to Estrada do Mar road (2943’9"S, 5056’0"W), 20 Nov 2003, L. R. Malabarba, J. Giora, J. Anza \& D. Cognato. MNRJ 30915, 2 (1 male, 69.9 mm LEA, 1 female, $85.2 \mathrm{~mm} \mathrm{LEA),} \mathrm{Cidreira,} \mathrm{lagoa}$ Fortaleza (30॰8'58"S, 50¹4'30"W), 11 Jul 2003, L. R. Malabarba. UFRGS 6671, 3 (2 males, 85.7-107.0 mm LEA, 1 female, 96.3 mm LEA), Terra de Areia, creek into rio Três Forquilhas, along the road RS486 (29³3’22"S, 504'19"W), 20 Nov 2003, L. R. Malabarba, J. Giora, J. Anza \& D. Cognato. Rio Uruguay drainage: UFRGS 6748, 1 (male, 90.8 mm LEA), Rosário do Sul, Sanga do Jacaré, BR290 (30¹2’4"S, 55³'17"W), 18 Jun 2004, D. Cognato, W. Crampton, J. Giora \& D. Rocha. MZUSP 94428, 8 (2 males, 95.6126.7 mm LEA, 6 females, 51.9-103.94 mm LEA), UFRGS 6753, 1 (male, 88.3 mm LEA), Rosário do Sul, stream tributary of arroio Gueromana, BR290 (30' $\left.1^{\prime} 00^{\prime \prime} S, 5^{\circ} 23^{\prime} 18^{\prime \prime} W\right), 19$ Jun 2004, D. Cognato, W. Crampton, J. Giora \& D. Rocha. UFRGS 6785, 4 (2 males, 79.3-105.1 mm LEA, 2 females, 84.5-85.3 mm LEA), UFRGS 6494, 1 (male, $92.5 \mathrm{~mm}$ LEA), UFRGS 6497, 1 (male, $90.1 \mathrm{~mm}$ LEA), Rosário do Sul, sanga do Jacaré, BR290 (30¹2`42"S, 55³'17"W), 26 Nov 2003, L. R. Malabarba, J. Giora, D. Cognato, G. Neves \& J. Ferrer. UFRGS 6789, 4 (2 males, 106.5-126.3 mm LEA, 2 females, 71.5-80.0 mm LEA), Rosário do Sul, stream tributary of arroio Gueromana, BR290 ( $\left.30^{\circ} 1^{\prime} 0{ }^{\prime \prime} \mathrm{S}, 5^{\circ} 23^{\prime} 18^{\prime \prime} \mathrm{W}\right), 26 \mathrm{Nov}$ 2003, L. R. Malabarba, J. Giora, D. Cognato, G. Neves \& J. Ferrer. UFRGS 6507, 1 (male, 92.9 mm LEA), UFRGS 6509, 1 (male, 92.5 mm LEA), UFRGS 6511, 1 (male, 98.3 mm LEA), São Gabriel, stream tributary of arroio Piraí, BR290 (30¹8’56"S, 54²4’22"W), 26 Nov 2003, L. R. Malabarba, J. Giora, D. Cognato, G. Neves \& J. Ferrer.

Non-type material. The following specimens were used to record the distribution of the new species, but are not used in the species description and are not part of the type series. However, they do not differ in morphometric or meristic characteristics from the type specimens. Brazil, Rio Grande do Sul: MCP 20215, 5, and MCP 20217, 3, Eldorado do Sul; MCP 20711, 1, Osório; UFRGS 7686, 


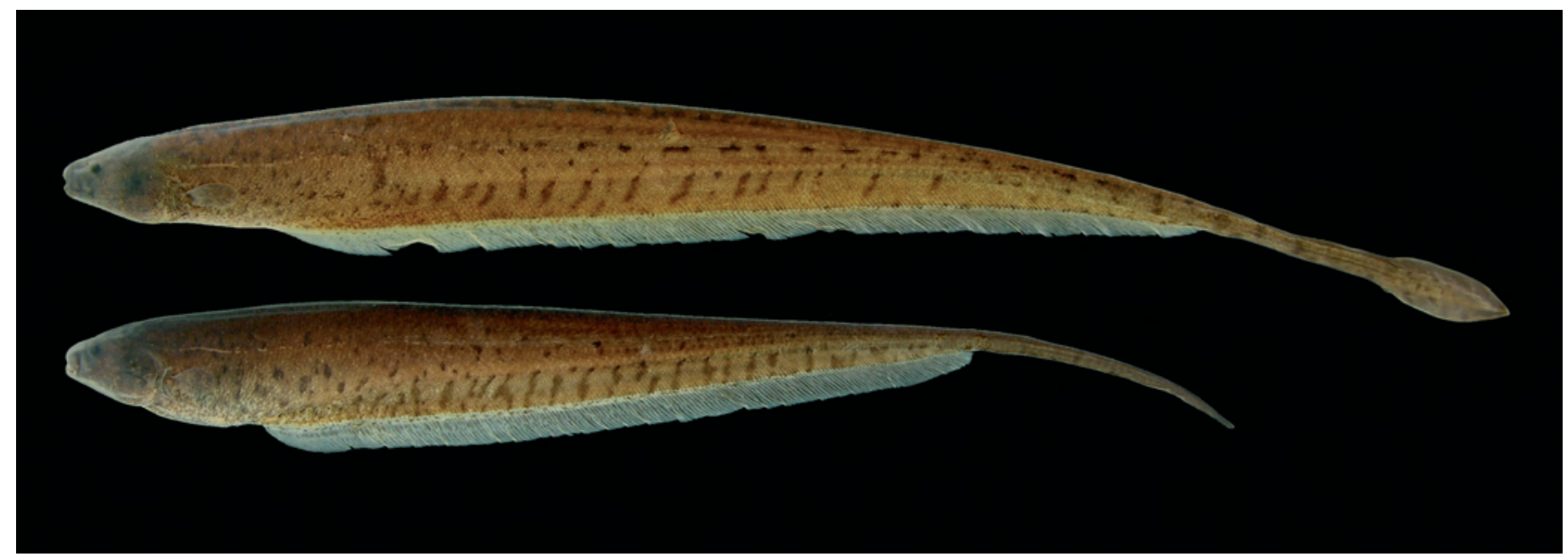

Fig. 1. Holotype (MCP 41540, male, 137.3 mm LEA, above) and paratype (MCP 41537, female, 108.4 mm LEA, below) of Brachyhypopomus draco, from Parque Estadual de Itapuã, Rio Grande do Sul, Brazil.

30, Viamão, and UFRGS 7707, 3, Viamão; UFRGS 8475, 4, Pantano Grande - Rio Pardo; UFRGS 8938, 1, rio Tramandaí; UFRGS 6780, 11, São Gabriel; UFRGS 6750, 14, Rosário do Sul - Alegrete; UFRGS 8263, 28, Charqueadas. Paraguay: USNM 181483, 5, Pueblo Ybytymi, Departamiento Paraguarí; ANSP 170412, 1, Deparatamiento Missiones; ANSP 175180, 1, Departamiento Missiones. Uruguay: ZVC-P 2727, 1, Departamiento Artigas, lagoa Redonda.

Diagnosis. Brachyhypopomus draco can be distinguished from all described congeners by the extreme broadening of the distal portion of the caudal filament in males during the reproductive period to form a distinct paddle shaped structure (vs. moderately broadened distally in B. pinnicaudatus and $B$. brevirostris into paddle-shaped structures, and versus broadened along most of the length of the caudal filament in B. occidentalis, B. diazi, B. beebei, and $B$. janeiroensis). Brachyhypopomus draco can be further diagnosed from other species of the genus by the following characters: caudal filament length $17.3-35.2 \%$ of LEA (vs. 36.5$50.0 \%$ in B. jureiae; $33.0-50.0 \%$ in B. janeiroensis, and 13.3$20.0 \%$ in B. bombilla); pectoral fin ray length $4.1-5.8 \%$ of LEA (vs. 6.7-7.9\% in B. pinnicaudatus); body depth $8.8-12.2 \%$ of LEA (vs. 12.1-16.2\% in B. pinnicaudatus); snout length 20.7$30.0 \%$ of HL (vs. 31.7-32.2\% in B. jureiae); gape width 9.5$16.5 \%$ of HL (vs. $17.8-23.1 \%$ in B. pinnicaudatus); interorbital distance $22.7-35 \%$ of HL (vs. 14.9-20.5\% in B. bombilla); branchial aperture $16.5-26 \%$ of HL (vs. $24.9-31.0 \%$ in $B$. pinnicaudatus); head width at operculum $48.4-65 \%$ of HL (vs. 60.0-73.0\% in B. pinnicaudatus); head width at eyes 31.3$45.6 \%$ of HL (vs. 24.7-31.7\% in B. bombilla); number of anal fin rays 155-198 (vs. 188-211 in B. jureiae; 251-295 in $B$. brevirostris; 214-228 in B. beebei, and 200-240 in $B$. occidentalis); upper jaw equal to lower jaw (vs. upper jaw slightly longer than lower jaw in B. bombilla, B. occidentalis, B. diazi, B. brevirostris and B. jureiae).
Description. Morphometric and meristic data are presented in Table 1. Head conical, nearly triangular in lateral view, snout short, eyes small, mouth terminal with upper jaw equal to lower jaw, no teeth in both jaws. Body slender, slightly laterally compressed. Dorsal profile straight from snout to supraoccipital, slightly convex posteriorly to caudal filament. Ventral profile gently convex from lower jaw to anal-fin origin, slightly convex to nearly straight along anal-fin base. Highest body depth located posterior to anal-fin origin. Body depth increasing smoothly from head to body region near the 30th anal-fin ray, clearly gradually decreasing from that point to caudal filament. Caudal filament moderately short, slender and laterally compressed in females, juveniles and males in non-reproductive period; caudal filament paddle-shaped in sexually mature males (see sexual dimorphism, below). Cycloid scales covering uniformly the body, except head and fins. Scales smaller on all anterior quarter portion of body; posterior scales at dorsal and medial body regions two to four times larger in diameter than anterior ones; smallest scales covering region of anal-fin pterygiophores. First anterior perforated scale of lateral line above pectoral fin origin and lateral line extending to caudal filament tip, hardly discernible. Branchial aperture small and slightly anterior to pectoral fin origin. Anus with the presence of urogenital papilla in males and females, although less developed in juveniles. Pectoral fins rounded with pigmented rays and perpendicular insertion; pectoral-fin rays i-ii + 13-15 (15-17 total pectoral-fin rays, $n=47$, median $=16$ ). Anal fin relatively long with vii-xii +148 186 rays (155-198 total anal-fin rays, $n=41$, mean $=181.3$ ) which are pigmented. Anal-fin origin located posterior to posterior edge of pectoral fin. Precaudal vertebrae 21-23 (20-22 anterior, 1-2 transitional; $\mathrm{n}=6$ ).

Coloration in life. General body color brownish varying from dark brown to yellowish brown, dark brown near dorsal mid- 
Table 1. Morphometric data for Brachyhypopomus draco.

\begin{tabular}{|c|c|c|c|c|c|c|c|c|}
\hline \multirow[t]{2}{*}{ Character } & \multirow[t]{2}{*}{ Holotype } & \multirow[t]{2}{*}{$\mathrm{n}$} & \multirow{2}{*}{\multicolumn{2}{|c|}{ Minimum Maximum }} & Mean & L1 & L2 & SD \\
\hline & & & & & \multicolumn{4}{|c|}{ 95\% confidence limit } \\
\hline Length to the end of anal fin (mm) & 137.3 & 44 & 50 & 151.9 & 96.9 & & & 24.55 \\
\hline \multicolumn{9}{|c|}{ Percents of length to the end of anal fin } \\
\hline Head length & 10.1 & 44 & 9.4 & 14.2 & 11.4 & 11.08 & 11.69 & 1.00 \\
\hline Caudal filament length & 29.1 & 34 & 17.3 & 35.2 & 25.1 & 23.32 & 26.86 & 5.15 \\
\hline Snout to anal fin origin & 18.3 & 44 & 17.9 & 23.0 & 20.3 & 19.93 & 20.70 & 1.27 \\
\hline Depth of caudal filament & 2.7 & 44 & 1.4 & 3.1 & 2.1 & 2.01 & 2.24 & 0.38 \\
\hline Longest anal fin ray & 3.7 & 43 & 2.9 & 4.4 & 3.6 & 3.52 & 3.73 & 0.34 \\
\hline Longest pectoral fin ray & 4.1 & 41 & 4.1 & 5.8 & 5.0 & 4.85 & 5.16 & 0.50 \\
\hline Body depth & 9.4 & 44 & 8.8 & 12.2 & 10.8 & 10.52 & 11.08 & 0.92 \\
\hline \multicolumn{9}{|c|}{ Percents of head length } \\
\hline Snout length & 26.5 & 50 & 20.7 & 30.0 & 25.6 & 25.12 & 26.08 & 1.68 \\
\hline Gape width & 14.5 & 50 & 9.5 & 16.5 & 13.7 & 13.32 & 14.14 & 1.45 \\
\hline Orbital diameter & 9.5 & 50 & 9.4 & 14.4 & 12.3 & 11.90 & 12.64 & 1.30 \\
\hline Interorbital distance & 23.4 & 50 & 22.7 & 35.0 & 28.4 & 27.60 & 29.25 & 2.91 \\
\hline Posterior nare to eye & 3.4 & 49 & 2.9 & 5.4 & 4.2 & 4.04 & 4.34 & 0.52 \\
\hline Branchial aperture & 23.3 & 50 & 16.5 & 26.0 & 19.9 & 19.31 & 20.44 & 1.99 \\
\hline Head width at operculum & 54.1 & 50 & 48.4 & 65.0 & 57.0 & 55.96 & 57.96 & 3.50 \\
\hline Head width at eyes & 37.2 & 50 & 31.3 & 45.6 & 39.9 & 39.09 & 40.63 & 2.71 \\
\hline
\end{tabular}

line and clearing ventrally. A highly variable number of dark brown bands, well delineated or not, nearly perpendicular or oblique to longitudinal body axis, running posterodorsally from base of anal-fin rays to nearby lateral line and occurring from head to tip of caudal filament. Anal and pectoral-fin rays speckled brown, with hyaline inter-radial membranes. Adults and juveniles exhibit the same coloration pattern.

Secondary sexual dimorphism. During reproductive period, established through monthly variation analysis of male and

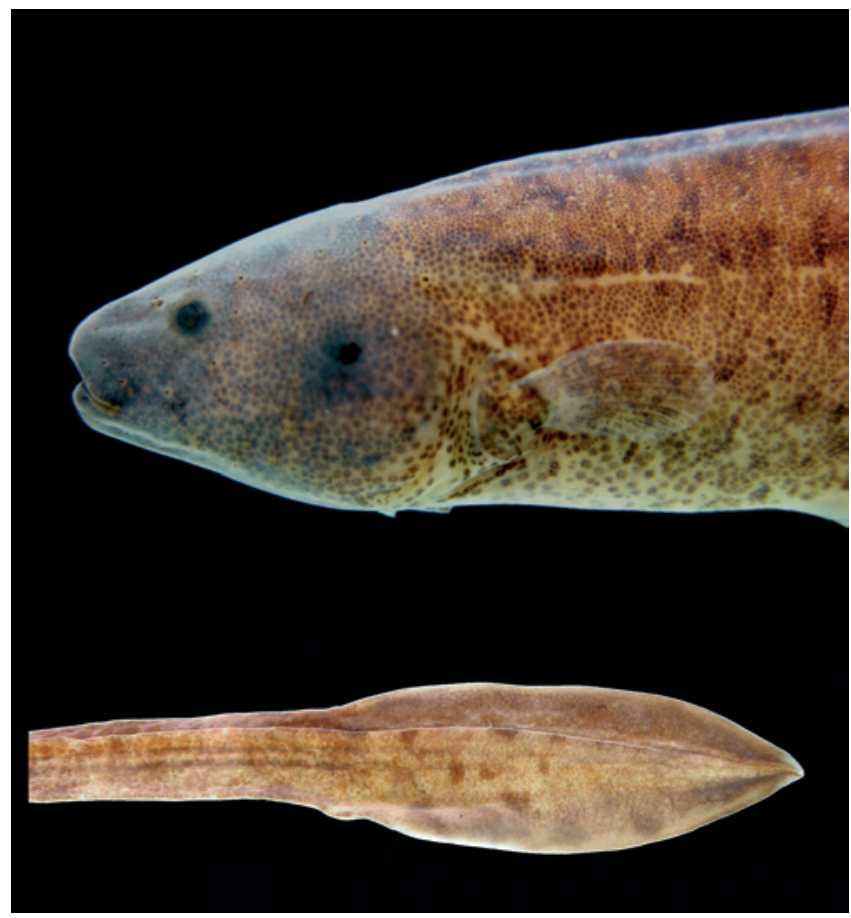

Fig. 2. Brachyhypopomus draco (holotype, MCP 41540, male, 137.3 mm LEA). Detailed images of head, above, and tail, below. female gonads in a B. draco population, males undergo hypertrophy of the distal portion of caudal filament (Fig. 2). This has been observed between August and December in a population studied from the type-locality (A. Schaan, J. Giora and C. Fialho, in preparation). Extremely vertical broadening and lateral compression give the caudal filament a paddle-like shape. After the reproductive period, this structure regresses until the caudal filament resembles those of females and juveniles. In addition, adult males are significantly larger than females.

Electric organ discharge. Brachyhypopomus draco generates a continuous train of pulse-type EODs. Adult specimens (with developing or fully developed gonads) (72.6-105 mm LEA) exhibited the following EOD parameters. The mean EOD repetition rate (per individual) during the day ranged from $15.7-24.6 \mathrm{~Hz}$ (mean among all specimens, $19.6 \mathrm{~Hz}, \mathrm{SD} 2.5, \mathrm{n}=$ 11 individuals fishes), with a standard deviation (SD) of 0.4$1.2 \mathrm{~Hz}$ (mean 0.7, SD 0.3, $\mathrm{n}=11$ ), and coefficient of variance of 1.8-7.0 \% (mean 3.9\%, SD 1.88, $\mathrm{n}=11$ ). The lowest and highest absolute pulse rates recorded from all diurnal recordings were 13.7 and $29.2 \mathrm{~Hz}$ respectively. During the hours of peak foraging activity, 1-3 hours after sunset, the mean EOD repetition rate (per individual) ranged from $34.2-45.8 \mathrm{~Hz}$ (mean among all specimens $38.6 \mathrm{~Hz}$, SD 5.2, $\mathrm{n}=6$ ) with a standard deviation of 2.8-10.8 Hz (mean 2.9, SD 1.1, $\mathrm{n}=6$ ) and a coefficient of variation of 8.3-27.3 \% (mean $20.7 \%, n=6$ ). The lowest and highest absolute pulse rates recorded from all nocturnal recordings were 8.4 and $80.2 \mathrm{~Hz}$ respectively.

In sum, adult specimens of $B$. draco exhibited a distinct increase in pulse rate from the resting day-time state (mean 19.6 Hz) to the nocturnal active state (mean $38.6 \mathrm{~Hz}$ ). The coefficient of variation of pulse rate during nocturnal activity (mean $20.7 \%$ ) was considerably higher than during the day (mean 3.9\%) reflecting the greater variability in pulse rate 
during foraging. Disturbances such as minor vibrations provoked novelty responses, sudden increases in the resting pulse rate from the baseline rate (Fig. 3). The approximately stable resting diurnal EOD punctuated by novelty responses results in a right-skewed distribution of inter-pulse intervals in a histogram (Fig. 3). Some specimens of $B$. draco displayed spontaneous complete cessations of the EOD for periods of up to 1 minute. Normal EOD activity was resumed after these interruptions.

The EODs waveforms of adult specimens of $B$. draco comprised two components of alternating polarity (P1 and P2) sensu Crampton \& Albert (2006), and varied in duration from 1.172-1.992 ms (mean 1.578, SD 0.147, $\mathrm{n}=23$ ) (Fig. 4). The Peak Power Frequency (PPF) (see Fig. 4) of these EODs varied from $0.6958-0.8942 \mathrm{kHz}$ (mean 0.7707, SD 0.0534, $\mathrm{n}=23$ ).

We did not encounter evidence for obvious sexual differences in the EOD waveforms of $B$. draco, despite evidence for this phenomenon in other species of Brachyhypopomus (e.g. B. occidentalis, Hagedorn, 1985, Shumway \& Zelick,
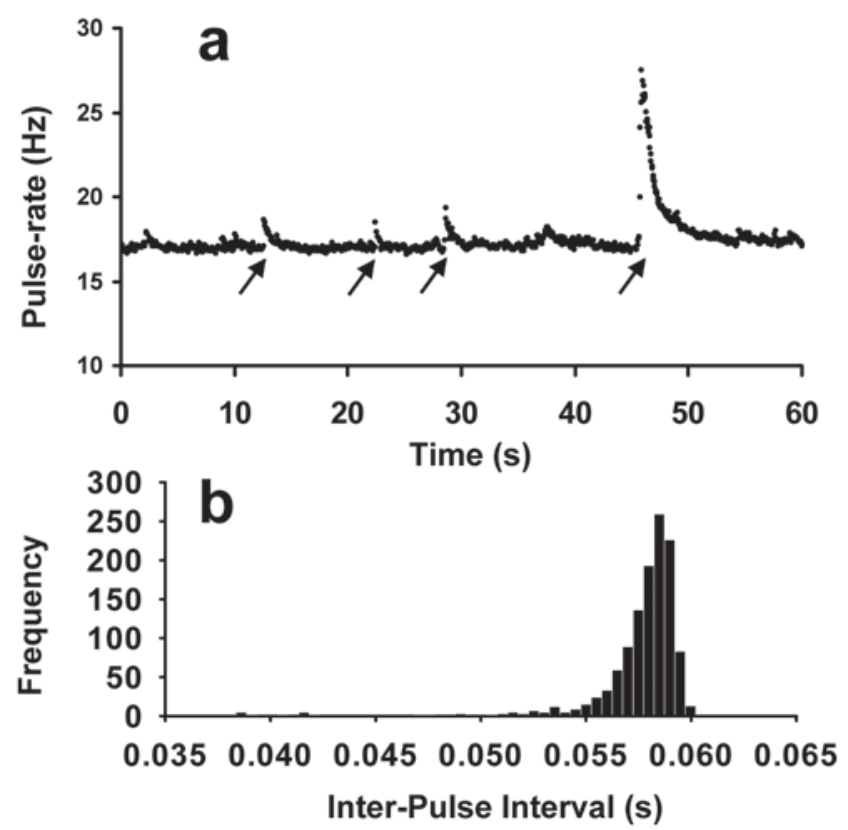

Fig. 3. a. Resting diurnal Electric Organ Discharge (EOD) repetition rate of a single specimen of Brachyhypopomus draco (UFRGS 6487). Repetition rate in $\mathrm{Hz}$ (pulses per second) is plotted for a $60 \mathrm{~s}$ recording. Each point represents the distance from an EOD to the preceding one (Inter-Pulse Interval, IPI). Note the intermittent upward modulations of repetition rate (arrows) in response to disturbances such as minute vibrations. These 'novelty responses' are a normal part of EOD activity in the wild. b. Histogram of 1218 IPIs for the $60 \mathrm{~s}$ recording, exhibiting a typical right-skewed distribution due to the novelty responses. Repetition rate $(\mathrm{Hz})$ is the reciprocal of Inter-pulse interval (e.g. $1 / 20 \mathrm{~Hz}=0.05 \mathrm{~s}$ ).
1988; B. pinnicaudatus Stoddard et al., 2003; B. brevirostris, Kawasaki \& Heiligenberg, 1989, Crampton, 1996). Where a sexual difference exists, this is manifest as an elongation of the second negative waveform phase, P2 and a corresponding reduction in the PPF of the EOD. We observed no consistent EOD waveform shape differences. Likewise, we observed no significant difference between the PPF of five sexually mature males $(0.7504-0.8942 \mathrm{kHz}$, mean 0.8178 , SD 0.0675$)$ and 2 sexually mature females $(0.7385-0.7949 \mathrm{kHz}$, mean 0.7667 , SD 0.0399) (2-sample T-test, $\mathrm{df}=5, \mathrm{n}=7, \mathrm{P}=0.38$ ). The observation of a lower PPF in mature females than males contrasts with cases of sexual EOD differences in Brachyhypopomus, where sexually mature males invariably display lower PPFs. Nonetheless, we did note that the Spectral Power Densities of the two sexually mature females exhibited a more rapid decline from the PPF than in the five sexually mature males (Fig. 4). Males and females with developing gonads also exhibited no obvious difference in waveform shape, and no significant difference in the PPF (males: 0.6958-0.8362 Hz, mean 0.7518, SD 0.0460, $\mathrm{n}=10$; females: $0.7111-0.8194 \mathrm{kHz}$, mean 0.7642, SD 0.0422, $\mathrm{n}=6$ ) (2-sample T-test, $\mathrm{df}=14, \mathrm{n}=16, \mathrm{P}=$ $0.59)$. All recorded specimens had been held in social isolation for several days before they were recorded. This is known to minimize the hormonally-induced modulation of the P2 phase in sexually mature males (Stoddard et al., 2003). Further investigation is required to explore whether EOD differences emerge in males that are exposed to normal social stimuli (i.e. the presence of sexually mature conspecifics).

All recordings presented here were made during the southern summer (December) when ambient water temperature is typically in the range $24-30^{\circ} \mathrm{C}$. During the winter, water temperatures in Rio Grande do Sul decline to as low as $10^{\circ} \mathrm{C}$. We noted that these seasonal temperature changes have a significant impact on the waveform duration and shape of the EODs of B. draco. The PPF of the EOD declines substantially, and the $\mathrm{P} 2$ phase becomes diminished in relative amplitude. We will present detailed observations on this phenomenon elsewhere. Loureiro \& Silva (2006) discuss the effect of temperature on the EODs of B. bombilla.

Distribution. Brachyhypopomus draco is widely known from central, southern and coastal regions of Rio Grande do Sul state, Brazil, and Uruguay. It is known from three drainages: laguna dos Patos, rio Uruguay and rio Tramandaí, and was also found at two localities in Paraguay (ANSP 170412; ANSP 175180; USNM 181483).

Habitat. Brachyhypopomus draco inhabits river edges, slowmoving creeks, lagoons and flooded areas with muddy or sandy bottom and abundant emergent or floating vegetation. The species was particularly abundant in the type locality, a

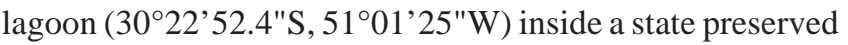



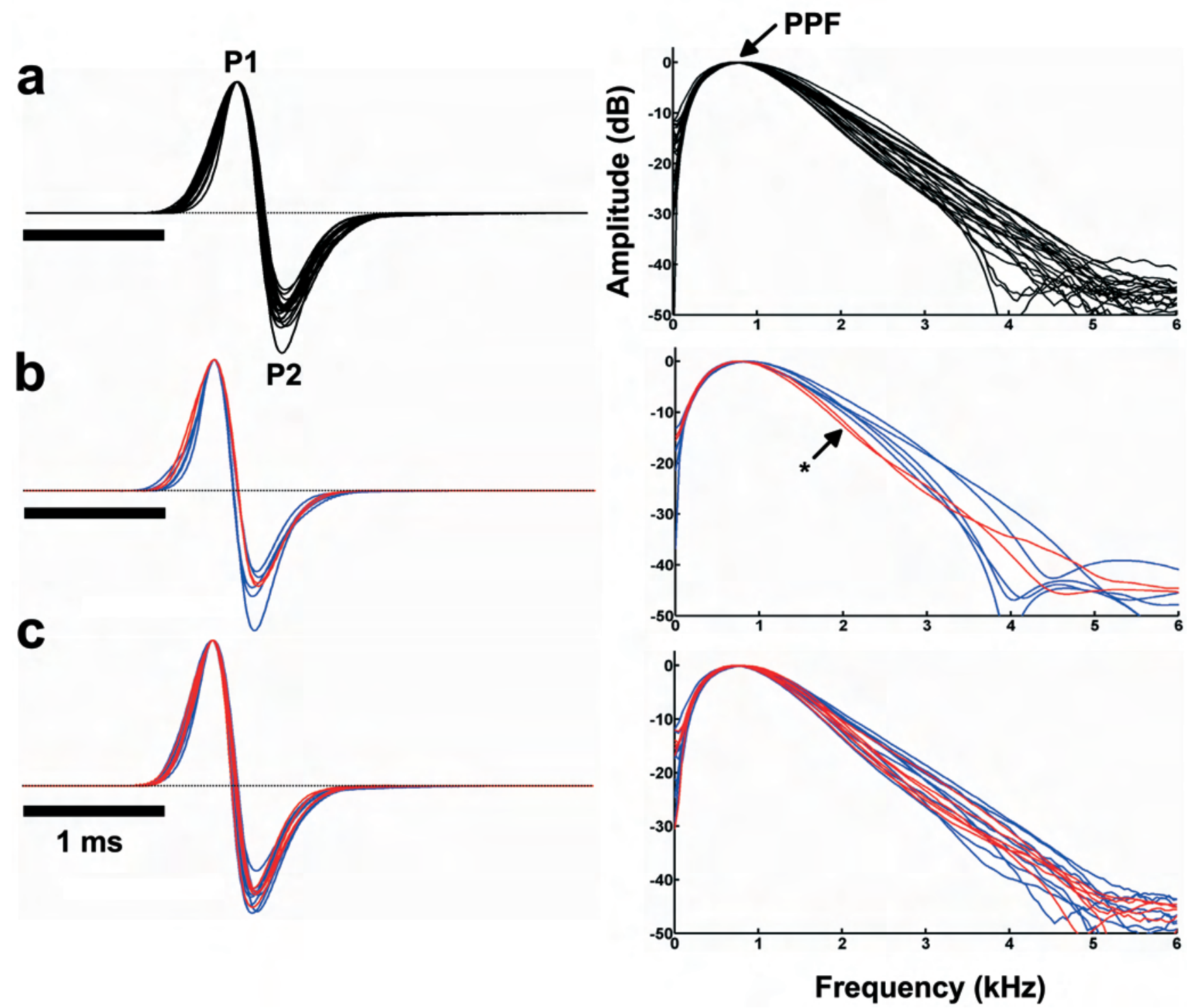

Fig. 4. Electric Organ Discharge (EOD) waveform (left) and Spectral Power Density (right) of adult specimens of Brachyhypopomus draco from Rio Grande do Sul state, Brazil. a: All 23 recorded specimens with developing or fully developed gonads (86-135 mm). b: 7 adult specimens with fully mature gonads; 5 male (blue) 2 female (red). c: 16 adult specimens with developing gonads; 10 males (blue), 6 females (red). EODs plotted with head positivity upwards, normalized to the amplitude of the dominant positive phase (P1), and aligned at the P1 peak. Scale bar $=1 \mathrm{~ms}$. Spectral Power Densities (SPDs) were computed from a 65, 536-point Fast Fourier Transform and the Peak Power Frequency (PPF) scaled to $0 \mathrm{~dB}$. Upper and lower ranges of the PPF are marked with arrows. Note the more rapid decline of the SPDs of the two sexually mature females versus males (labeled with asterisk in c) but no obvious sexual difference in EOD waveform shape or PPF.

area, Parque Estadual de Itapuã in Rio Grande do Sul, Brazil. The lagoon is approximately 4 hectares in area and reaches 1 meter in depth. It has a muddy bottom, abundant macrophytes and vegetal material in various stages of decomposition, and is surrounded by psammophilous forest with strong vegetational influence from Atlantic forest formations (Fig. 6). At the type locality, B. draco was found occurring together with an undescribed Gymnotus (Crampton et al., in prep.). At other collecting sites throughout Rio Grande do Sul state the spe- cies was collected along with the gymnotiforms Eigenmannia trilineata, B. bombilla and another undescribed Brachyhypopomus species (see Comparative Material).

Etymology. Name "draco”, from the Greek "drakon” meaning dragon, in reference to the shape of distal portion of caudal filament in mature males, similar to that illustrated in these imaginary creatures. 


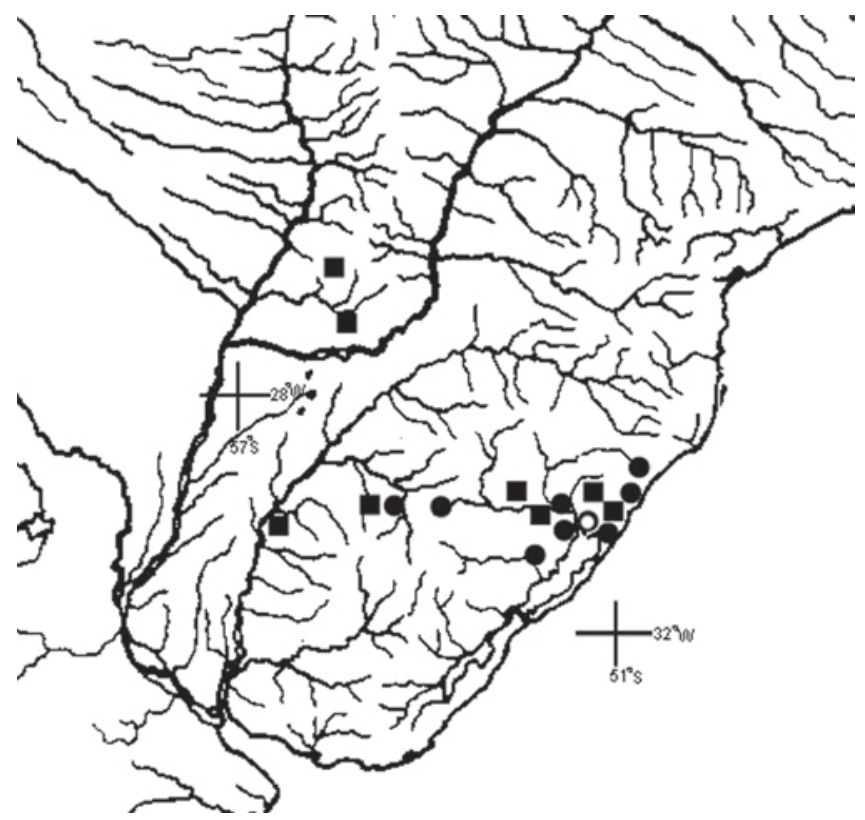

Fig. 5. Map of Southern Brazil, Uruguay, Argentina and Paraguay with the distribution of Brachyhypopomus draco. Squares represent non-type specimens. Empty circle represents the type locality.

\section{Discussion}

The new species is referred to the genus Brachyhypopomus, since it conforms to diagnoses of the genus proposed by Mago-Leccia (1994) and Albert (2001). The new species lacks a mesocoracoid bridge, presents a short snout, a short and crescent-shaped maxillary bone, and posterior nares closer to eyes than to snout tip, as proposed in Mago-Leccia’s (1994) diagnosis.

Albert (2001) considered the characters used by MagoLeccia (1994) ambiguous in his analysis, and proposed four other characters to diagnose the genus. Brachyhypopomus draco possesses two of these: the premaxilla gracile with a curved anterior margin and forming a distinct angle with the maxilla in lateral view, and the dentary gracile. The two other characters used by Albert (2001) were the presence of a single transitional vertebra and body cavity with $16-17$ precaudal vertebrae (20-21, with the addition of C1-C4).

We observed 21-23 precaudal vertebrae in B. draco (2022 anterior, $1-2$ transitional; $n=6$ ). The number of transitional vertebrae exhibited variability, with three of six specimens bearing one transitional vertebra; two bearing one transitional vertebra, and one vertebra associated to a rib (but not completely developed, and not attached to the vertebra); and one bearing two transitional vertebrae. Variability in the number of precaudal and transitional vertebrae has also been observed in B. bombilla (Loureiro \& Silva, 2006).

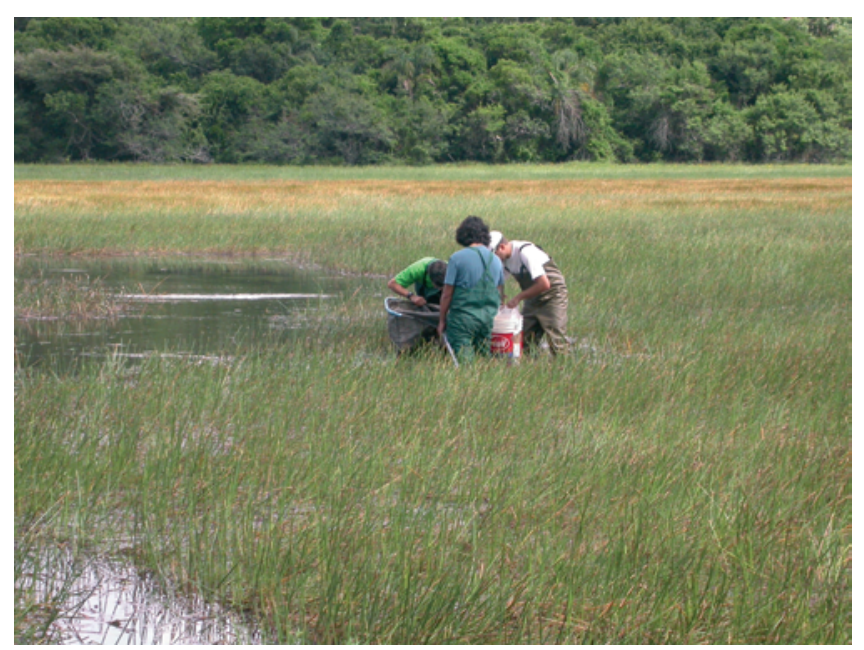

Fig. 6. Typical habitat of Brachyhypopomus draco; marshland in the Parque Estadual de Itapuã, Rio Grande do Sul, Brazil.

From a study of both morphological and molecular sequence data, Sullivan (1997) diagnosed five species groups within Brachyhypopomus, discussed later by Albert (2001): the $B$. brevirostris group, consisting of $B$. brevirostris and one undescribed species; the $B$. beebei group, including $B$. beebei, B. pinnicaudatus, B. janeiroensis, and two undescribed species, and the $B$. occidentalis group, including $B$. occidentalis and $B$. diazi. Within the $B$. beebei species group, two subgroups were established: one clade consisting of two undescribed species, and another consisting of $B$. beebei and B. pinnicaudatus. Brachyhypopomus draco can be included in the $B$. beebei species group, sharing all the group characteristics: lower jaw equal to upper jaw; ventral ethmoid reduced; fourth supraorbital lateral line pore close to vertical through posterior nares; and supraorbital lateral line canal not attached to frontal rostral to the orbit. Nevertheless, $B$. draco cannot be included in any of the $B$. beebei subgroups because it does not share any of their characteristics.

Although $B$. draco is more closely related to B. beebei, $B$. pinnicaudatus, and $B$. janeiroensis, included in the $B$. beebei group, it can be easily distinguished from these species. In addition to the presence of the paddle-shaped tail in mature males and the morphometric and meristc characters presented in diagnosis, the coloration pattern of B. draco also differs from these Brachyhypopomus species. According to the diagnoses presented by Sullivan (1997), B. beebei has a narrow depigmented stripe running along the posterior half of upper dorsum, B. pinnicaudatus has a nearly solid dark brown pigment over the dorsum broken by fine unpigmented reticulations, and $B$. janeiroensis lacks lateral bands along sides of the body in mature individuals. All these color patterns diverge from $B$. draco that presents a dark brown dorsal surface with a variable number of darker bands, nearly perpen- 
dicular or oblique to the longitudinal body axis. Moreover, the clade consisted of $B$. beebei and B. pinnicaudatus is diagnosed by the presence of a tiny hook-like ossification medial to first branchiostegal ray (Sullivan, 1997; Albert, 2001), which is absent in B. draco.

The undescribed species referred herein as occurring in Rio Grande do Sul can also be diagnosed from B. draco by the lack of a paddle-shaped distal portion of caudal filament in mature males, and by the coloration pattern, showing dorsal surface of the body with chocolate-brown stains that form a reticulated drawing contrasting with a yellow background. Furthermore, B. draco has the anal-fin origin located posterior to posterior edge of the pectoral fin (versus anal-fin origin located at the same line of posterior edge of the pectoral fin in the undescribed species).

Comparative material. Brachyhypopomus bombilla: ZVC-P 6287, Holotype, Uruguay, Rocha Departamiento, rio Cuatro Palmas; ZVCP 5688, 1, Paratype, Uruguay, rio Quebracho; ZVC-P 5686, 10, 3cs, Uruguay, Rocha Departamiento, rio San Luiz; ZVC-P 5685, 1, Uruguay, Tacuarembo Departamiento, rio Batovi; UFRGS 9282, 15, UFRGS 9273, 18, UFRGS 9284, 17, UFRGS 6741, 1, UFRGS 6742, 1, UFRGS 6745, 1, UFRGS 6496, 1, UFRGS 6495, 1, Brazil, Rio Grande do Sul, Rosário do Sul; Brachyhypopomus jureiae: DZUFMG 011, 2, Paratype, Brazil, São Paulo, rio do Descavado, Juréia Ecological Station; Brachyhypopomus pinnicaudatus: ANSP 163463, Holotype, 1, French Guiana; ANSP 163464, Paratype, 1, French Guiana; USNM 301966, Paratype, 1, French Guiana; USNM 301967, Paratype, 1, French Guiana; USNM 301968, 1, French Guiana; UMMZ 216032, Paratype, 3, French Guiana; Brachyhypopomus sp.: UFRGS 6520, 1, UFRGS 6524, 1, UFRGS 8932, 1, Brazil, Rio Grande do Sul, Viamão, Parque Estadual de Itapuã, lagoa Negra; UFRGS 2219, 2, Brazil, Rio Grande do Sul, Santo Antônio da Patrulha; UFRGS 3844, 2, Brazil, Rio Grande do Sul, Capão da Canoa, lagoa dos Quadros; UFRGS 6499, 1, UFRGS 6503, 1, UFRGS 6504, 1, UFRGS 6505, 1, Brazil, Rio Grande do Sul, São Gabriel.

\section{Acknowledgments}

We are grateful to David Catania (CAS), John Lundberg and John Sullivan (ANSP), Marcelo Loureiro (ZVC-P), Zilda Margarete Lucena (MCP), Mauro Triques (DZUFMG), and Richard Vari and Stanley Weitzman (USNM) for the loan of specimens. The first author was funded by CAS, ANSP and CAPES to travel and visit museum collections. This project was supported by CNPq (process 476821/2003-7; 478002/20068). WGRC was funded by National Science Foundation grant DEB-0614334.

\section{Literature Cited}

Albert, J. S. 2001. Species diversity and phylogenetic systematics of American knifefishes (Gymnotiformes, Teleostei). Miscellaneous Publications of the Museum of Zoology,
University of Michigan, 190: 1-127.

Albert, J. S. \& W. G. R. Crampton. 2003. Seven new species of the neotropical electric fish Gymnotus (Teleostei, Gymnotiformes) with a redescription of $G$. carapo (Linnaeus). Zootaxa, 287: 1-54.

Campos-da-Paz, R. 1997. Sistemática e taxonomia dos peixes elétricos das bacias dos rios Paraguai, Paraná e São Francisco, com notas sobre espécies presentes em rios costeiros do leste do Brasil (Teleostei: Ostariophysi: Gymnotiformes). Unpublished Ph. D. Thesis, Universidade de São Paulo, São Paulo, Brazil.

Cognato, D. De P. \& C. B. Fialho. 2006. Reproductive biology of a population of Gymnotus aff. carapo (Teleostei: Gymnotidae) from Southern Brazil. Neotropical Ichthyology, 4(3): 339348.

Costa, W. J. E. M. \& R. Campos-da-Paz. 1992. Description d'une novelle espèce de poisson eléctrique du genre néotropical Hypopomus (Siluriformes: Gymnotodei: Hypopomidae) du sudest du Brésil. Revue Française d’Aquariologie, 18(4): 117120.

Crampton, W. G. R. 1996. The electric fish of the Upper Amazon: ecology and signal diversity. Unpublished Ph. D Thesis, The University of Oxford, Oxford. 223p.

Ellis, M. M. 1913. The gymnotid eels of tropical America. Memoirs of the Carnegie Museum, 6(3): 109-195.

Fernández-Yépez, A. 1972. Análisis ictiológico del complejo hidrográfico (04) "Río Yaracuy". Direccion de Obras Hidraulicas, Ministerio de Obras, Republica de Venezuela. 25 p., 41pl.

Hagedorn, M. 1985. Ecology and behaviour of a pulse-type electric fish, Hypopomus occidentalis (Gymnotiformes, Hypopomidae), in a fresh-water stream in Panama. Copeia, 1985(2): 324-335.

Hopkins, C. D. 1991. Hypopomus pinnicaudatus (Hypopomidae), a new species of gymnotiforme fish from French Guiana. Copeia, 1991(1): 151-161.

Kawasaki, M. \& W. Heiligenberg. 1989. Distinct mechanisms of modulation in a neuronal oscillator generate different social signals in the electric fish Hypopomus. Journal of Comparative Physiology A., 165: 731-741.

Loureiro, M. \& A. Silva. 2006. A new species of Brachyhypopomus (Gymnotiformes: Hypopomidae) from Northeast Uruguay. Copeia, 2006(4): 665-673.

Mago-Leccia, F. 1978. Los peces de la familia Sternopygidae de Venezuela. Acta Cientifica Venezolana, 29 (suppl. 1): 1-89.

Mago-Leccia, F. 1994. Electric fishes of the continental waters of America. Caracas, Fundacion para el Desarrollo de las Ciencias Fisicas, Matematicas y Naturales. Electric Fishes: 1-206.

Malabarba, L. R. 1989. Histórico sistemático e lista comentada das espécies de peixes de água doce do sistema da laguna dos Patos, Rio Grande do Sul, Brasil. Comunicações do Museu de Ciências da PUCRS (Sér. Zool.), 2(8): 107-179.

Regan, C. T. 1914. Fishes from Condoto River, Colômbia, collected by Dr. H. G. F. Spurrel. Annals and Magazine of Natural History, 14(79): 31-33.

Schultz, L. P. 1944. Two new species of fishes (Gymnotidae, Loricariidae) from Caripito, Venezuela. Zoologica, 29(1): 3944.

Shumway, C. A. \& R. D. Zelick. 1988. Sex recognition and neuronal coding of electric organ discharge waveform in the pulse-type 
weakly electric fish, Hypopomus occidentalis. Journal of Comparative Physiology A., 163: 465-478.

Steindachner, F. 1868. Abhandlung über die Gymnotiden des Wiener Museums. Anzeiger der Akademie der Wissenschaften in Wien, 5(20): 176-177.

Stoddard, P. K., M. R. Markham \& V. L. Salazar. 2003. Serotonin modulates the electric waveform of the gymnotiform electric fish Brachyhypopomus pinnicaudatus. Journal of Experimental Biology, 206: 1353-1362.

Sullivan, J. P. 1997. A phylogenetic study of the Neotropical hypopomid electric fishes (Gymnotiformes: Rhamphichthyoidea). Unpublished Ph. D. Dissertation. Duke University, Durham, North Carolina.
Taylor, W. R. \& G. C. Van Dyke. 1985. Revised procedures for staining and clearing small fishes and other vertebrates for bone and cartilage study. Cybium, 9:107-119.

Triques, M. L. \& D. K. Khamis. 2003. Brachyhypopomus jureiae, a new species of freshwater Neotropical electric fish (Teleostei: Gymnotiformes: Hypopomidae) from a coastal stream of southeastern Brazil. Lundiana, 4(1): 61-64.

Wells, K. \& W. G. R. Crampton. 2006. A portable bio-amplifier for electric fish research: design and construction. Neotropical Ichthyology, 4 (2): 295-299.

Accepted February 2008

Published June 28, 2008 